\title{
Body Mass Index and Its Relation to Blood Pressure in Preclinical Students of the Faculty of Dentistry, Padjadjaran University
}

\author{
Vella Atika ${ }^{1}$, Rosiliwati Wihardja ${ }^{2 *}$, Kartika Indah Sari ${ }^{2}$ \\ ${ }^{1}$ Faculty of Dentistry, Padjadjaran University, Bandung 40134, Indonesia \\ ${ }^{2}$ Department of Oral Biology, Faculty of Dentistry, Padjadjaran University, Bandung 40134, \\ Indonesia \\ *Email: rosywihardja@yahoo.com
}

\begin{abstract}
Body Mass Index (BMI) and blood pressure have become the subjects of epidemiological studies. Both BMI and blood pressure have a parallel relationship. Usually, as BMI increases, both systolic and diastolic blood pressures increase. The purpose of this research is to discover the relationship between BMI and blood pressure of preclinical students of the Faculty of Dentistry, Padjadjaran University. This investigation is an analytical study with a correlational approach. Total sampling yielded a population of 156 students. The research was carried out by recording students' weight, height, and blood pressure. Data analysis was performed using Pearson correlation analysis. Results showed that $15.38 \%$ of students were underweight, $53.85 \%$ were normal, $14.74 \%$ were overweight, $13.46 \%$ were class I obese, and $2.56 \%$ were class II obese. As for their systolic blood pressure, $9.62 \%$ were hypotensive, $85.26 \%$ were normal, and $5.13 \%$ were prehypertensive. Finally, the results of the students' diastolic blood pressures showed that $7.69 \%$ were hypotensive, $73.72 \%$ were normal, $16.03 \%$ were prehypertensive, and $2.56 \%$ were stage I hypertensive. It is concluded that there is a very weak correlation between BMI (Body Mass Index) and blood pressure of preclinical students of the Faculty of Dentistry, Padjadjaran University.
\end{abstract}

Keywords: body mass index, blood pressure

\section{Introduction}

Obesity and being overweight are health problems that occur in almost all countries around the world, as risk factors that can lead to cardiovascular disease. These factors have shown a close relationship with the occurrence of hypertension. Hypertension is another disease of concern in many countries around the world because it often represents the number one infectious disease in many countries [1].

Approximately 972 million people or $26.4 \%$ of the world's population currently suffer from hypertension worldwide, and this level is expected to increase to $29.2 \%$ around 2025[2]. In Indonesia, the prevalence of hypertension in the 18 years or older age group in this region is $30.8 \%$ [3]. Body mass index (BMI) and both positive systolic and diastolic blood pressure have parallel relationships. Both systolic and diastolic blood pressures increase with increasing BMI [4,5]. This research was conducted on preclinical students of the Faculty of Dentistry at Padjad- 
jaran University, with the hope that this research could be useful for health practitioners. The purpose of this research is to know BMI and how it is related to blood pressure in preclinical student Faculty of Dentistry at Padjadjaran University.

\section{Materials and Method}

Descriptive, analytical research using a correlation approach was conducted in 2017. In this research, 156 preclinical students of the dentistry faculty of Padjadjaran University were selected as respondents by using a total sampling technique that met the inclusion criteria out of the total population of 178 students. Respondents were asked to fill out a questionnaire consisting of 18 questions related to factors that could affect both BMI and blood pressure. This questionnaire used information about the lifestyle of respondents from supporting research to enable this additional material to be associated with the research results. This study included measurements of BMI taken once and measurements of blood pressure of respondents taken twice. The BMI is the result of measurements from the weight calculation expressed in kilograms $(\mathrm{kg})$, divided by the height measured using a stature meter expressed in square meters $(\mathrm{m} 2)$. The BMI is classified as underweight $(<18.5 \mathrm{~kg} / \mathrm{m} 2)$, normal $(18.5-22.9 \mathrm{~kg} / \mathrm{m} 2)$, and overweight: at risk (23-24.9 $\mathrm{kg} / \mathrm{m} 2)$, obesity level I (25-29.9 kg/m2), obesity level II ( $\geqslant 30 \mathrm{~kg} / \mathrm{m} 2)$ [2]. Blood pressure is the result of measurements of systolic (sbp) per diastolic number (dbp) to be shown by a mercury sphygmomanometer expressed in millimeters of mercury $(\mathrm{mmHg})$, and classified as normal $(<120-180)$, prehypertension (sbp: 120-139, dbp: 80-89), grade I hypertension (sbp: 140-159, dbp: 90-99), grade 2 hypertension $(\geqslant 160-100)$, and crisis hypertension (>180-110) [6].

In this research, the data were analyzed using the Pearson correlation analysis used to determine the strength of the association between both independent and dependent variables.

\section{Result and Discussion}

The BMI of respondents is known to most students that $53.85 \%$ have normalized BMI, followed by underweight $15.38 \%$, overweight $14.74 \%, 13.46 \%$ obesity level I, and $2.56 \%$ obese level II (Fig 1.).

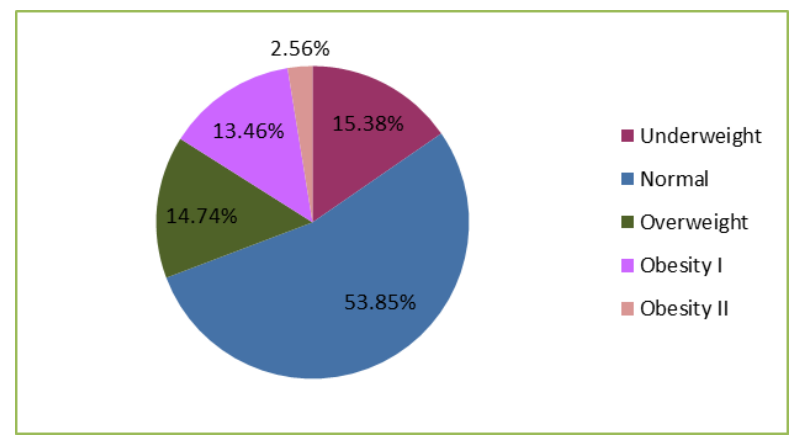

Fig 1. Respondents' Body Mass Index Category 
Most students (85.26\%) had normal systolic blood pressure, followed by $9.62 \%$ who had hypotension, and $5.13 \%$ had systolic prehypertension, whereas hypertension category I, hypertension II, and crisis hypertensive were not found in this research (Fig 2).

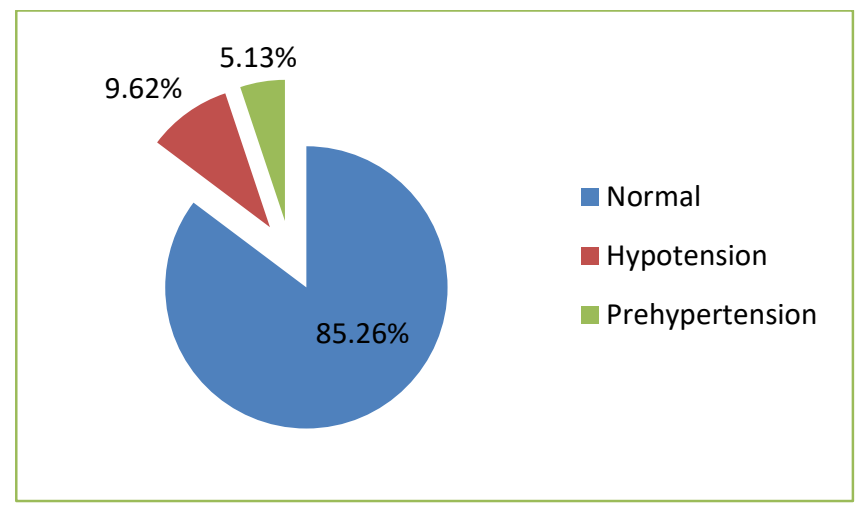

Fig 2. Respondents' Systolic Blood Pressure

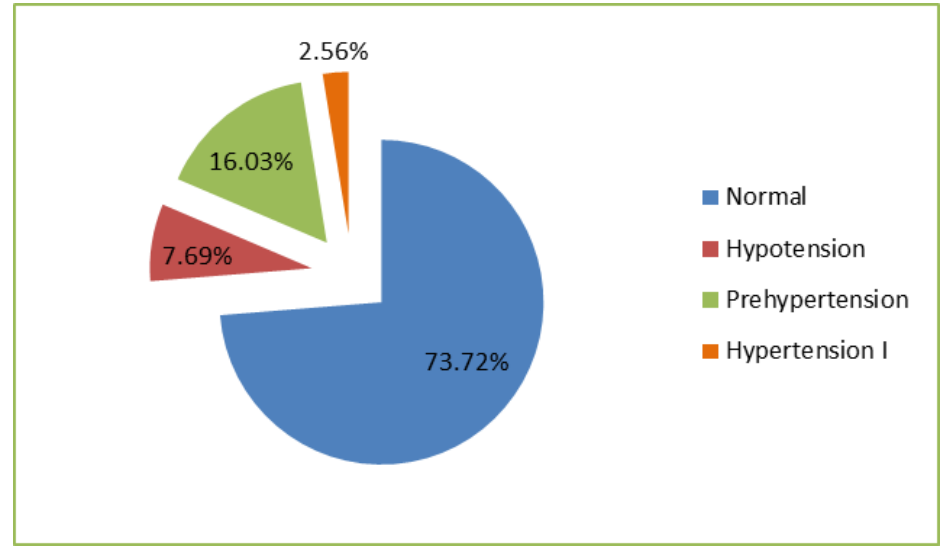

Fig 3. Respondents' Diastolic Blood Pressure

Diastolic blood pressure of respondents represented the largest percentage of the normal categorized amount(73.72\%), followed by $16.03 \%$ who had prehypertension, $7.69 \%$ who had hypotension of diastolic blood pressure, and $2.56 \%$ who had level I hypertension of diastolic blood pressure, whereas the categories of hypertension level II and crisis hypertension were not found (Fig 3).

The correlation value obtained between the BMI as measured by systolic blood pressure was 0.158 . The correlation between BMI as measured by diastolic blood 
pressure was 0.147 . Based on the interpretation of the correlation coefficient, values of 0.158 and 0.147 fall into very weak categories of relationships (Table 1).

Table 1. Correlation of Body Mass Index and Blood Pressure

\begin{tabular}{|c|c|c|c|c|}
\hline Variable & $\mathbf{n}$ & $\mathbf{R}$ & p-value & Criteria \\
\hline $\begin{array}{l}\text { Correlation of BMI and Systolic } \\
\text { Blood Pressure }\end{array}$ & 156 & 0.158 & 0.049 & Very Low \\
\hline $\begin{array}{l}\text { Correlation of BMI and Diastolic } \\
\text { Blood Pressure }\end{array}$ & 156 & 0.147 & 0.066 & Very Low \\
\hline
\end{tabular}

Based on research results, $53.85 \%$ of respondents are in the normal category, and $15.38 \%$ in the underweight category. It can be affected by the fat level point that presents in the individual body. If the fasting lipid profile is high, the body will try to store more fat. Many factors that can affect the BMI of students remain in the normal category. Dense physical activity such as lectures can drain student' energy. Regular physical activity can prevent weight gain and significantly reduce weight in the long term [7]. The results of the study for the above normal BMI category show a percentage of $30.76 \%$ (overweight $14.74 \%$, obesity level I $13.46 \%$, and obesity level II $2.56 \%$ ). The BMI is influenced by genetic factors. If the parent suffers from overweight then the chances of the child being overweight by $40 \%-50 \%$. If a parent is obese, their child may become obese by $70 \%-80 \%$ [8]. Low physical activity is a major factor that can affect the BMI. The results of questionnaires showed that $77 \%$ of students admitted rarely exercise. Respondents who did not exercise regularly had an obesity risk of 1.35 times compared with regular exercise respondents [9].

A review of the questionnaire results with a question about their feelings regarding lectures on dentistry at Padjadjaran University revealed that $57 \%$ of students admitted that they were happy, 24\% were satisfied, 9\% were very happy, and $5 \%$ confessed that they were stress. Stress can increase blood pressure over time, but when the stress is gone, blood pressure returns to normal levels. Feeling relaxed and happy will activate the parasympathetic nervous system thereby lowering heart rate, respiratory rate, and blood pressure [11,17].

In addition, the results of the study also showed that the systolic blood pressure of $15(9.62 \%)$ students and diastolic blood pressure of $12(7.69 \%)$ students were in the hypotension category. Hypotension or low blood pressure can be caused by various factors such as mild or severe dehydration, lack of drinking, diet, sleep deprivation, heart muscle weakness, and some medications [12].

Furthermore, $8(5.13 \%)$ students had systolic blood pressure and $25(16.03 \%)$ students had diastolic blood pressure classified as prehypertension, and $4(2.56 \%)$ students had diastolic blood pressure, included in hypertension category I. Individuals who came from families with a history of hypertension, have a greater risk of developing hypertension. Modern molecular biotechniques have identified the genes responsible for the occurrence of hypertension in individuals. High salt consumption is also associated with the occurrence of hypertension. Several studies 
have shown that a reduction in salt intake can lower blood pressure by an average of 3-5 mmHg [13].

The results of the questionnaire showed that $77 \%$ of students admitted that they rarely exercised with $35 \%$ of them doing irregular exercise. This finding is in accordance with a study that states that individuals who do not exercise regularly have 44.1 times increased risk of hypertension compared with people who exercise regularly. Regular physical activity, such as exercise, can decrease peripheral resistance that will lower blood pressure and train the heart muscle, so it becomes accustomed to accommodating a heavier load under certain conditions. Regular exercise stimulates the release of endorphins that cause muscle relaxation, so that blood pressure does not increase [1,14].

The results of this study indicate that there is a very weak relationship between the BMI and both systolic and diastolic blood pressures. This result can happen because of several factors that cannot be controlled during the research. These factors include genetic, dietary, physical activity, and times of measurement that are considered less precise. The BMI is used in clinical practice to determine the presence and degree of overweight or obesity of a person, regardless of muscle mass. An individual blood pressure should be based on a diagnosis by repeated routine measurements under resting conditions, without anxiety, caffeine, alcohol, and nicotine to establish a diagnosis. Measurements should be taken at the clinic at least three times at different times of the week. It can affect the results of BMI measurements and blood pressure, so it shows a very weak relationship between the two $[15,16]$.

\section{Conclusion}

At the conclusion of the research that was done on the students of the Faculty of Dentistry, Padjadjaran University, it can be concluded that there is a relationship between BMI and blood pressure, but the relationship is very weak. The limitation of this study lies with the questionnaire that causes research respondents sometimes to provide answers that may not reflect the real situation. In addition, there are scheduling difficulties and other logistical issues to consider when inviting research respondents with different schedules.

\section{References}

1. Anggara FH, Prayitno N. Faktor-faktor yang berhubungan dengan tekanan darah di Puskesmas Telaga Murni, Cikarang Barat tahun 2012. Jurnal Ilmiah Kesehatan. 2013;5(1):20-5.

2. The Asia Pacific perspective: Redefining obesity and its treatment [Internet]. WHO Western Pacific Region. 2018. Available from: http://www.wpro.who.int/nutrition/documents/Redefining_obesity/en/

3. Departemen Kesehatan. Laporan Nasional Riset Kesehatan Dasar (Riskesdas). Jakarta: Badan Litbangkes; 2008.

4. Krzyżaniak A, Stawińska-Witoszyńska B, Kaczmarek M, Krzywińska-Wiewiorowska M, Siwińska A. Percentile distribution of blood pressure readings in relation to body mass index: a population based cross-sectional study ADOPOLNOR. Anthropolog Rev. 2015;78(1):91-106. 
5. Tesfaye F, Nawi NG, Van Minh H, Byass P, Berhane Y, Bonita R, Wall S. Association between body mass index and blood pressure across three populations in Africa and Asia. J Hum Hyperten. 2007 Jan;21(1):28.

6. Understanding Blood Pressure Readings [Internet]. Heart.org. 2016. Available from: http://www.heart.org/HEARTORG/Conditions/HighBloodPressure

7. Jakicic JM, Otto AD. Physical activity considerations for the treatment and prevention of obesity. Am J Clin Nutr. 2005;82(1):226S-9S.

8. Sartika RA. Faktor risiko obesitas pada anak 5-15 tahun di Indonesia. Makara J Health Res. 2011;15(1):37-43.

9. Mustelin L, Silventoinen K, Pietiläinen K, Rissanen A, Kaprio J. Physical activity reduces the influence of genetic effects on BMI and waist circumference: a study in young adult twins. Int J Obesity. 2009;33(1):29.

10. Masud I. Dasar-dasar fisiologi kardiovaskuler. Jakarta: EGC. 2007.

11. Sulistyarini I. Terapi relaksasi untuk menurunkan tekanan darah dan meningkatkan kualitas hidup penderita hipertensi. Jurnal Psikologi. 2013;40(1):28-38.

12. Gustrawan, I.G.K, Muliarta, I.M. Studi Deskriptif untuk Mengetahui Rata-rata Penurunan Tekanan Darah Setelah Olahraga Futsal selama 15 Menit. E-Jurnal Medika. 2016;5(7).

13. Saing JH. Hipertensi pada remaja. Sari Pediatri. 2016 Dec 5;6(4):159-65.

14. Rahardja, E.M. Faktor gizi dalam regulasi tekanan darah. Ebers Papyrus. 2004;10:16572.

15. Brown CD, Higgins M, Donato KA, Rohde FC, Garrison R, Obarzanek E, Ernst ND, Horan M. Body mass index and the prevalence of hypertension and dyslipidemia. Obesity. 2000;8(9):605-19.

16. Kuswardhani T. Penatalaksanaan hipertensi pada lanjut usia. Jurnal Penyakit Dalam. 2006;7(2):135-40. 